\title{
Lipase Production by Solid-State Fermentation in Fixed-Bed Bioreactors
}

\author{
Elisa d'Avila Costa Cavalcanti ${ }^{1}$, Melissa Limoeiro Estrada Gutarra ${ }^{1}$, Denise Maria \\ Guimarães Freire $^{1 *}$, Leda dos Reis Castilho ${ }^{2}$ and Geraldo Lippel Sant'Anna Júnior ${ }^{2}$ \\ ${ }^{1}$ Instituto de Química; ${ }^{2}$ Programa de Engenharia Química - COPPE; Universidade Federal do Rio de Janeiro; \\ freire@iq.ufrj.br; Ilha do Fundão, CT, lab. A-549; 21945-970; Rio de Janeiro - RJ - Brasil
}

\begin{abstract}
In the present work, packed bed bioreactors were employed with the aim of increasing productivity and scaling up of lipase production using Penicillium simplicissimum in solid-state fermentation. The influence of temperature and air flow rate on enzyme production was evaluated employing statistical experimental design, and an empirical model was adjusted to the experimental data. It was shown that higher lipase activities could be achieved at lower temperatures and higher air flow rates. The maximum lipase activity $(26.4 \mathrm{U} / \mathrm{g})$ was obtained at the temperature of $27^{\circ} \mathrm{C}$ and air flow rate of $0.8 \mathrm{~L} / \mathrm{min}$.
\end{abstract}

Key words: Solid-state fermentation, fixed-bed bioreactors, lipase, Penicillium simplicissimum

\section{INTRODUCTION}

Lipases are hydrolytic enzymes that act in aqueous-organic interfaces, catalysing the cleavage of ester bonds in triglycerides and producing glycerol and free fatty acids. However, in environments with low water availability, lipases are able to catalyse esterification, interesterification and transesterification reactions, being thus very versatile biocatalysts (Sharma et al., 2001; Pandey et al., 1999). Since the mid 1980 's, there is a growing interest for lipases, especially for those of microbial origin. Due to the different reactions lipases are able to catalyse and due to their regio and enantio selectivity, lipases find an increasing range of applications, such as in the detergent, food, pharmaceutical, fine chemicals, leather and pulp and paper industries (Freire and Castilho, 2000). However, an even greater industrial application of these enzymes would depend on the development of low-cost processes for the production of lipases.

In this context, solid-state fermentation (SSF) appears as an interesting low-cost alternative for the production of biomolecules. In SSF, agroindustrial residues can be employed as culture medium. These low-cost and abundant raw materials contribute to reduce production costs (Freire and Castilho, 2000). Additionally, SSF, which is characterized by microbial growth on moist solids, has proven to be an efficient way to produce enzymes, especially by filamentous fungi, since it provides the microorganisms with environmental conditions similar to their natural habitat (Pandey et al., 1999; Durand, 2003). However, industrial scale application of SSF is not yet fully developed. The low moisture contents used in SSF pose limitations to mass and heat tranfer, producing heterogeneous environments in full-scale bioreactors, which contribute to

\footnotetext{
*Author for correspondence
} 
overheating and deficient oxygen supply (Ashley et al., 1999; Mitchell et al., 1999). Due to these problems, very few types of SSF bioreactors are found in the literature (Couto et al., 2003). More research is needed in this field to allow successful industrial scale applications of the SSF process to be developed (Ashley et al., 1999).

Fixed-bed bioreactors are usually employed in solid-state fermentation. These reactors are generally cylindrical, and the solid medium (fixedbed) is retained in the reactor by a static support. Air flow is forced through the bed, assuring oxygen supply and heat removal. These reactors are recommended when the fermentation agents are filamentous fungi, because these organisms are able to colonize the solid medium and utilize the oxygen and the water vapour supplied by the moist air fed to the bed. In such reactors, the relevant operation parameters may be better controlled than in the traditional tray type fermenters (Ashley et al., 1999; Mitchell et al., 1999).

In this work, the production of lipase by the fungus Penicillium simplicissimum, cultivated in fixed-bed bench-scale bioreactors, was investigated. The effect of air flow rate and temperature on lipase production was assessed.

\section{MATERIALS AND METHODS}

\section{Microorganism}

Penicillium simplicissimum strain used in this work was isolated from the solid residues generated during the industrial processing of babassu seeds (Freire, 1996). The strain was maintained in glycerol $(30 \% \mathrm{v} / \mathrm{v})$ at $-20{ }^{\circ} \mathrm{C}$. Spores were obtained through strain propagation for 7 days at $30{ }^{\circ} \mathrm{C}$ in a culture medium containing (\% w/v): soluble starch $2.0, \mathrm{MgSO}_{4} .7 \mathrm{H}_{2} \mathrm{O} 0.025$, $\mathrm{KH}_{2} \mathrm{PO}_{4} 0.05, \mathrm{CaCO}_{3} 0.5$, yeast extract 0.1 , olive oil 1.0 and agar 1.0 (Gutarra, 2003).

\section{Solid-State Fermentation}

Fermentations were carried out in bench-scale fixed-bed bioreactors. The glass reactors had a cylindrical shape (4 cm diameter, $14 \mathrm{~cm}$ height) and a water jacket to maintain the fermentation temperature under control. Sterile and moist air was injected in the reactor bottom and air flow rate was measured with a rotameter.

The cultivation medium was babassu cake (a residue of the babassu oil production), supplemented with $6.25 \% \quad(\mathrm{w} / \mathrm{w})$ sugar cane molasses (Gutarra, 2003). The babassu cake was first crushed and screened in order to generate solid particles with diameters in the range of 0.21 $0.42 \mathrm{~mm}$. An amount of $30 \mathrm{~g}$ of culture medium was used in the bench-scale reactors. The medium and the bioreactor were separately sterilized in autoclave. Before packing the solid medium in the sterile reactor, it was inoculated with $10^{7} \mathrm{spores} / \mathrm{g}$ and its moisture content was adjusted to $70 \%$.

The fermentation experiments were carried out according to a statistical experimental design. The experimental matrix (Table 1) shows the absolute values of the variables temperature $(T)$ and air flow rate $(\mathrm{Q})$ tested, as well as their normalized values $\left(\mathrm{T}^{*}\right.$ and $\left.\mathrm{Q}^{*}\right)$. The experimental results were analyzed using the software Statistica and an empirical model was obtained, relating lipase activity level (U/g) with $\mathrm{T}^{*}$ and $\mathrm{Q}^{*}$.

Further experiments were performed exploiting the production of lipase under operational conditions different from those shown in Table 1. The experimental results obtained were compared with those predicted by the model. These additional experiments were performed at 29 and $35^{\circ} \mathrm{C}$, employing air flow rates of $0.1,0.3,0.7$ and 1.0 L/min.

\section{Enzyme Extraction}

After fermentation, the fermented solids were removed from the reactor and transferred to a glass flask. Sodium phosphate buffer $(135 \mathrm{~mL}, 100 \mathrm{mM}$, $\mathrm{pH}$ 7.0) was added to the flask, which was incubated in a rotary shaker $(200 \mathrm{rpm})$ at $35^{\circ} \mathrm{C}$ for $20 \mathrm{~min}$. The extract was obtained by manually pressing the material, followed by centrifugation (3000 rpm, 2 min) (Gutarra, 2003).

\section{Lipase Activity Determination}

Lipase activity of the extracts was determined as follows: $1 \mathrm{~mL}$ of extract was added to $19 \mathrm{~mL}$ of an emulsion prepared with olive oil $(5 \% \mathrm{w} / \mathrm{v})$ and arabic gum $(10 \% \mathrm{w} / \mathrm{v})$ in sodium phosphate buffer (100 mM, pH 7.0). The reaction was carried out under agitation $(200 \mathrm{rpm})$ at $35^{\circ} \mathrm{C}$ for $30 \mathrm{~min}$. The reaction was stopped by the addition of $20 \mathrm{~mL}$ of acetone-ethanol mixture (1:1) and the fatty acids produced were extracted under agitation $(200 \mathrm{rpm})$ for $10 \mathrm{~min}$ and titrated until end-point $(\mathrm{pH}$ 11.0) with $\mathrm{NaOH}$ solution $(0.04 \mathrm{~N})$. The blank assays were performed by adding the extract just after the addition of the acetone-ethanol solution to the flask. One unit of lipase activity (U) was defined as the amount of enzyme, which produces $1 \mu$ mole 
fatty acids per minute under the assay conditions (Gombert et al., 1999). The enzyme activity was expressed as unit of lipase activity per dried mass of fermented material $(\mathrm{U} / \mathrm{g})$.

\section{Moisture Content Determination}

Moisture content of the fermented material was obtained by weighing crude and dried solid samples. Drying of $0.5 \mathrm{~g}$ samples was performed at $75{ }^{\circ} \mathrm{C}$ until constant weight.

Table 1 - Response surface experimental design: absolute and normalized variable values.

\begin{tabular}{l|r|r|r|r}
\hline Run & \multicolumn{2}{|c|}{ Temperature } & \multicolumn{2}{c}{ Air flow rate } \\
\hline & $\boldsymbol{T}\left({ }^{\circ} \mathbf{C}\right)$ & $\boldsymbol{T}^{*}$ & $\boldsymbol{Q}$ (L/min) & $\boldsymbol{Q}^{*}$ \\
\hline 1 & 25.8 & -1.41 & 0.50 & 0 \\
2 & 27.0 & -1 & 0.20 & -1 \\
3 & 27.0 & -1 & 0.80 & 1 \\
4 & 30.0 & 0 & 0.08 & -1.41 \\
5 & 30.0 & 0 & 0.50 & 0 \\
6 & 30.0 & 0 & 0.50 & 0 \\
7 & 30.0 & 0 & 0.50 & 0 \\
8 & 30.0 & 0 & 0.92 & 1.41 \\
9 & 33.0 & 1 & 0.20 & -1 \\
10 & 33.0 & 1 & 0.80 & 1 \\
11 & 34.2 & 1.41 & 0.50 & 0 \\
\hline
\end{tabular}

Table 2 - Results of lipase activity obtained in different experiments.

\begin{tabular}{ccccc}
\hline Run & Temperature $\left({ }^{\circ} \mathbf{C}\right)$ & Air flow $(\mathbf{L} / \mathbf{m i n})$ & Lipase Activity $(\mathbf{U} / \mathbf{g})$ \\
\hline 1 & 25.8 & 0.50 & 16.7 \\
2 & 27.0 & 0.20 & 19.6 \\
3 & 27.0 & 0.80 & 26.4 \\
4 & 30.0 & 0.08 & 18.8 \\
5 & 30.0 & 0.50 & 20.6 \\
6 & 30.0 & 0.50 & 21.5 \\
7 & 30.0 & 0.50 & 20.3 \\
8 & 30.0 & 0.92 & 20.9 \\
9 & 33.0 & 0.20 & 12.1 \\
10 & 33.0 & 0.80 & 11.2 \\
11 & 34.2 & 0.50 & 18.7 \\
\hline
\end{tabular}

\section{RESULTS AND DISCUSSION}

The results of lipase activity obtained in the experiments carried out according to the experimental design are shown in Table 2. The highest lipase level $(26.4 \mathrm{U} / \mathrm{g})$ was attained when fermentation was carried out at $27^{\circ} \mathrm{C}$ with an air flow rate of $0.8 \mathrm{~L} / \mathrm{min}$.

The statistical analysis of the experimental data led to the empirical model represented by Equation 1 . Lipase activity (LA, in U/g) was expressed as a function of the normalized temperature $\left(\mathrm{T}^{*}\right)$ and air flow rate $\left(\mathrm{Q}^{*}\right)$. Although the correlation coefficient obtained was not high $(\mathrm{R}=0.72)$, all the terms presented a high statistical significance (plevel lower than 0.05), except for the quadratic term of the air flow rate, which showed a slightly lower significance level $(\mathrm{p}=0.085)$.

$$
\begin{aligned}
L A= & 20.79-2.46 T^{*}-1.91 T^{* 2}+1.11 Q^{*}- \\
& -0.85 Q^{* 2}-1.93 T^{*} Q^{*}
\end{aligned}
$$

The comparison between the experimental data and the activity values predicted by the empirical model (Equation 1) is illustrated in Fig. 1. The contour plot of the lipase activity values predicted by the empirical model is shown in Fig. 2. 
As observed in Fig. 2, in the variable ranges studied, higher lipase activities could be achieved by carrying out the fermentation at lower temperatures and higher air flow rates. The negative effect of temperature on the production of lipase by $P$. simplicissimum cultivated in babassu cake medium was earlier observed in tray-type reactors by Gutarra (2003), who found high levels of proteases when fermentation was carried out at higher temperatures. Thus, the enhanced production of proteases at higher temperatures could be responsible for the decrease in lipase activity observed under such conditions. Beyond proteolysis, enzyme deactivation could be another factor contributing to lipase activity decrease at higher temperatures.

Gutarra (2003) determined $28.8^{\circ} \mathrm{C}$ as the optimum temperature for lipase production in tray-type reactors. However, in the present work, it was observed that temperatures below $28{ }^{\circ} \mathrm{C}$ appeared more adequate to reach high levels of lipase production. It should be mentioned, however, that the temperature was measured in the reactor water jacket and not inside the bed.

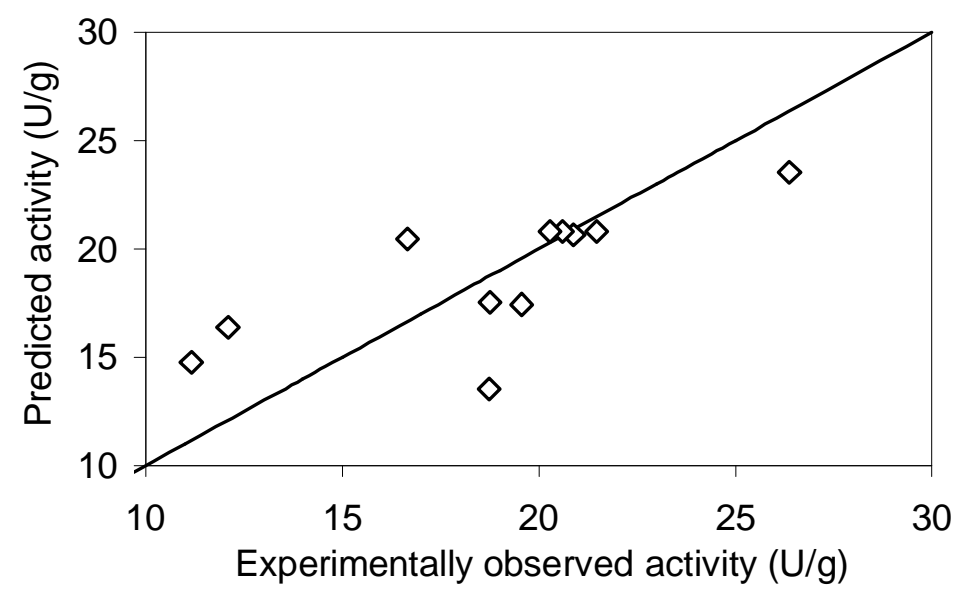

Figure 1 - Experimentally observed lipase activities and values predicted by Equation (1).

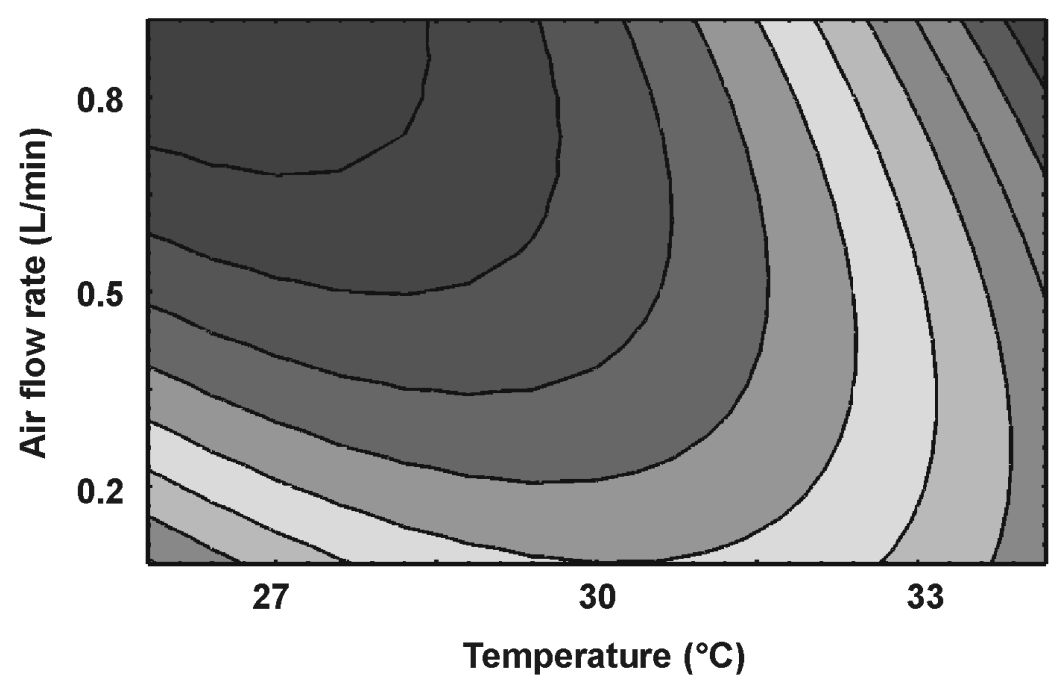

Figure 2 - Contour plot of lipase activity as a function of temperature and air flow rate. 
Thus, the temperature in the bed may be higher than $28^{\circ} \mathrm{C}$. Temperature gradients may be significant, even in bench-scale bioreactors, as mentioned by Saucedo-Castañeda et al. (1990), who found radial temperature differences up to $10^{\circ} \mathrm{C}$ in fermentations in bench-scale reactors with the fungus Aspergillus niger.

Aeration showed to have a positive effect on lipase activity. Higher lipase levels were obtained when the air flow rate surpassed 0.7 $\mathrm{L} / \mathrm{min}$ (Fig. 2). Aeration is important to remove heat, since oxygen limitation is usually not a critical factor in such fermentation systems (Mitchell et al., 2003). Aeration could avoid the high temperatures reached in the bed, however, when excessive, it promotes overdrying of the bed, even when saturated air is injected in the bioreactor (Pandey and Radhakrishnan, 1993). Overdrying may lead to very low moisture contents in the bed, preventing microbial growth (Mitchell et al., 1999).
In all experiments, moisture content in the bed along fermentation remained close to the initial level $(70 \%)$. Variation on moisture content was confined in the range of 5\% (data not shown). Thus, overdrying did not occur in the experimental system employed in this work. Further experiments were performed (Table 3) to validate the empirical model represented by Equation 1. The results shown in Fig. 3 enabled the comparison between experimental and predicted results. Higher deviations were observed for the data obtained at $35^{\circ} \mathrm{C}$ (Fig. 3). This could be attributed to the fact that the model was developed based on a set of experiments obtained in the temperature range of 25.8 to $34.2^{\circ} \mathrm{C}$. Despite that, the overall results shown in Fig. 3 indicated that the empirical model was able to satisfactorily predict lipase production as a function of the independent variables, temperature and air flow rate.

Table 3 - Lipase activity values reached in additional experiments.

\begin{tabular}{c|c|c}
\hline Temperature $\left({ }^{\circ} \mathbf{C}\right)$ & Air flow rate $(\mathbf{L} / \mathbf{m i n})$ & Lipase Activity $(\mathbf{U} / \mathbf{g})$ \\
\hline 29.0 & 0.10 & 15.14 \\
29.0 & 0.30 & 17.02 \\
29.0 & 0.70 & 20.69 \\
29.0 & 1.00 & 20.87 \\
35.0 & 0.10 & 8.91 \\
35.0 & 0.30 & 11.25 \\
35.0 & 1.00 & 9.09 \\
\hline
\end{tabular}

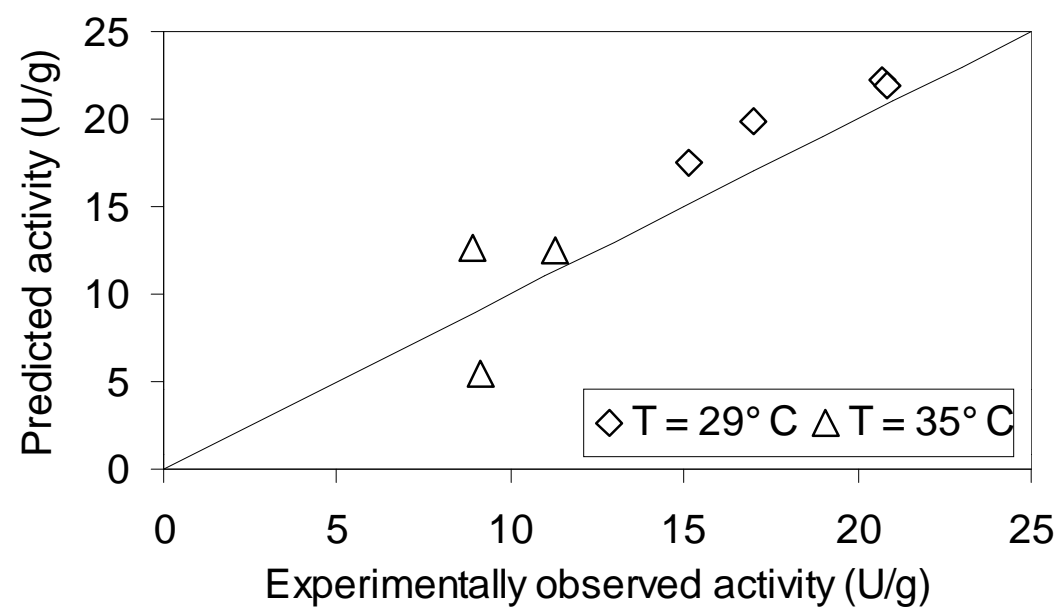

Figure 3 - Comparison between experimental values (Table 3) and predicted values (Eq. 1). 


\section{CONCLUSIONS}

The best conditions for lipase production by $P$. simplicissimum in bench-scale fixed-bed bioreactors were determined $\left(27^{\circ} \mathrm{C}\right.$ and air flow rate of $0.8 \mathrm{~L} / \mathrm{min}$ ). Under these conditions, the cultivation of the fungus in the medium containing babassu cake and sugar cane molasses led to a lipase activity of $26.4 \mathrm{U} / \mathrm{g}$. The empirical model obtained from the statistical analysis of the experimental data was able to describe the effect of the independent variables (temperature and air flow rate) on lipase production. Furthermore, the model was able to predict experimental lipase activity levels for a relatively large interval of operation conditions.

\section{ACKNOWLEDGEMENTS}

Authors express their gratitude to the Brazilian agencies FAPERJ and CNPq, and to the company TOBASA S.A., which kindly supplied samples of babassu cake.

\section{RESUMO}

O fungo Penicillium simplicissimum se mostrou, em trabalhos anteriores, um ótimo produtor de lipase por fermentação no estado sólido, quando cultivado em biorreatores do tipo bandeja, utilizando a torta de babaçu como meio de cultura. Com o objetivo de aumentar a produtividade e possibilitar uma ampliação de escala, foi investigado, no presente trabalho, o emprego de biorreatores de leito fixo com aeração forçada. Os biorreatores utilizados tinham $4 \mathrm{~cm}$ de diâmetro interno e $14 \mathrm{~cm}$ de altura útil. Empregando-se planejamento estatístico de experimentos como ferramenta, foram avaliadas as influências da temperatura e da vazão de ar sobre a produção de lipase nestes biorreatores. Os resultados obtidos permitiram ajustar um modelo empírico, o qual indicou que maiores atividades lipásicas são alcançadas para temperaturas mais baixas e vazões de ar mais altas. A atividade lipásica máxima (26,4 $\mathrm{U} / \mathrm{g}$ ) foi obtida para temperatura de $27^{\circ} \mathrm{C}$ e vazão de ar de $0,8 \mathrm{~L} / \mathrm{min}$.

\section{REFERENCES}

Ashley, V. M.; Mitchell, D. A. and Howes, T. (1999), Evaluating strategies for overcoming overheating problems during solid-state fermentation in packed bed bioreactors. Biochem. Eng. J., 3, 141-150.

Couto, S. R.; Moldes, D.; Libébanas, A. and Sanromán, A. (2003), Investigations of several configurations for laccase production by Trametes versicolor operating in solid-state conditions. Biochem. Eng. J., 15, 21-26.

Durand, A. (2003), Bioreactor designs for solid state fermentation. Biochem. Eng. J., 13, 113-125.

Freire, D. M. G. (1996), Seleção de microorganismos lipolíticos e estudo da produção de lipase por Penicillium restrictum. PhD Thesis, Departamento de Bioquímica, IQ/UFRJ, Rio de Janeiro/RJ, Brazil

Freire, D. M. G. and Castilho, L. R. (2000), Lipases produzidas por fermentação submersa e em meio sólido. Rev. Bras. Farmácia, 81, 48-56.

Gombert, A. K.; Pinto, A. L.; Castilho, L.R. and Freire, D. M. G. (1999), Lipase production by Penicillium restrictum in solid-state fermentation using babassu oil cake as substrate. Process Biochem., 35, 85-89.

Gutarra, M. L. E. (2003), Produção de lipase por fermentação no estado sólido: seleção de fungos produtores e estudo das condições de cultivo. MSc Thesis, Departamento de Bioquímica, IQ/UFRJ, Rio de Janeiro/RJ, Brazil.

Mitchell, D. A.; Meien, O. F. V. and Krieger, N. (2003), Recent developments in modeling of solidstate fermentation: heat and mass transfer in bioreactors. Biochem. Eng. J., 13, 137-147.

Mitchell, D. A.; Pandey, A.; Penjit, S. and Krieger, N. (1999), Scale-up strategies for packed-bed bioreactors for solid-state fermentation. Process Biochem., 35, 167-178.

Pandey, A.; Benjamim, S.; Soccol, C. R.; Nigam, P.; Krieger, N. and Soccol, V. T. (1999), The realm of microbial lipases in biotechnology. Biotechnol. Appl. Biochem., 29, 119-131.

Pandey, A. and Radhakrishnan, S. (1993), The production of glucoamylase by Aspergillus niger NCIM 1245. Process Biochem., 28, 305-308.

Saucedo-Castañeda, G.; Gutiérrez-Rojas, M.; Bacquet, G.; Raimbault, M. and Viniegra-González, G. (1990), Heat transfer simulation in solid state fermentation. Biotechnol. Bioeng., 35, 82-808.

Sharma, R.; Chisti, Y. and Banerjee, U. C. (2001), Production, purification, characterization, and applications of lipases. Biotechnol. Adv., 19, 627-662.

Received: September 29, 2004; Revised: February 25, 2005; Accepted: March 25, 2005. 